that there is a considerable amount to be learnt about green manuring; the investigators, however, appear to be nearer to explaining the negative results, noted in the 1933 report, obtained by the use of green manures on the light soils of Woburn. The trials with poultry manure, commenced in 1933, have been continued with market garden crops, the manure having been compared with equivalent mixtures of sulphate of ammonia and superphosphate ; the nitrogen in the dried poultry manure did not prove so valuable as the nitrogen of sulphate of ammonia.

A valuable feature of the report is provided by articles on the contribution of the various departments to the study of soils and crops. Thus, work on soil physies is reported on by Dr. B. A. Keen, and that on the chemistry of soils and fertilisers by Dr. E. M. Crowther ; the contribution to soil bacteriology is discussed by Dr. H. G. Thornton, and that on general mierobiology by Mr. D. W. Cutler. In the Soil Physics Department, much attention has been given to the study of the plastic behaviour of soil and clay, work which is of interest to the ceramic industry as well as to the cultivator of the soil. Among the results of theoretical interest may be mentioned the grave doubts thrown on the reality of 'structure turbulence' and 'structure viscosity' in soil and clay pastes--subjects that have been extensively studied by other workers. In practical soil cultivation, the work touches aspects such as ploughing speed, and tilth. In the section dealing with soil cultivation, great importance must be attached to the studies on the effects of rotary cultivation. This method of tilth production is entirely new, and of great promise; the work at Rothamsted will give advisers and investigators definite information upon which to work. In Dr. Crowther's contribution, special interest is attached to the hypothesis which is put forward that, in a heavy soil, nitrate washed out of the surface may be stored in the structural units of the subsoil. To quote this report, "it soems possible that this hypothesis may serve to bridge the gulf between the pedologist's concern with the deeper horizons and the analyst's use of surface samples".

The Manager's report on the Rothamsted and Woburn farms, together with the notes on the weather. and on the insect and fungoid pests could not fail to interest any farmer. Indeed, the Rothamsted annual reports, in addition to their value to the agricultural scientific worker, can be recommended as deserving a place on the bookshelf of all intelligent farmers.

\title{
American Universities and Game-Rearing
}

$\mathrm{T}$ THE American universities have been conspicuous in their pioneer additions of practical subjects to the university curriculum, and it is particularly interesting, therefore, that, as J. N. Darling, Chief of the Bureau of Biological Survey, U.S. Department of Agriculture, describes in a paper in the September issue of Scientific American, 30,000 dollars for an endowment fund for five years has been offered by an anonymous U.S. arms' manufacturer to the Biological Survey for wild-life restoration and administration training at several of the State universities. It has been announced that several State universities are to set up courses in game management with the active support of the Bureau of Biological Survey, which will supply instructors and contribute 42,000 dollars; State and game conservation organisations will also combine in the scheme, and original research in wild-life subjects will be incorporated in the training course, as is done with the forestry training.

"The reservation of enough grazing lands to maintain a reasonable supply of our big game animals can be accomplished without infringing upon the reasonable requirements of the stock growers", Mr. Darling states. "The same is true of small game species. A few large reservations of the hereditary ranges, supplemented by development for wild-life purposes of waste lands, of odds and ends such as ravines, sloughs, roadside strips, fence rows and sub-marginal tracts will be sufficient to bring back wild creatures even in our intensively cultivated areas in more abundance than has been observed for two generations. . . On most land midway between fertility and bar renness, fish, game and furbearers can exist with far better profit to humanity than when given over to a desperate sort of agriculture. Throughout the U.S. the total drained areas equal $110,000,000$ acres."

Wild-life and game animals, and especially nonmigratory birds, have decreased markedly in the United States during this century, owing to extensive shooting with little organised game protection or conservation. Ten years ago, Maine alone produced more mink pelts than are now annually produced in all the United States. The trumpeter swan is confined to a few haunts, of which Yellowstone National Park is one. With State and Federal aid, a herd of 20,000 elk still exists in the Jackson Hole region of Wyoming. Within recent years the "More Game Birds in America" Foundation was formed and incorporated in New York to increase American game by the control of their natural enemies and the following of intensive game-rearing on lines similar to those adopted in Europe, particularly Great Britain, where since the passing of the Game Act of 1831 , partridge have increased more than 200 per cent and pheasants more than 1,000 per cent, and in the six years 1919-25, after War-time diminution, British gamekeepers increased the nation's stock of game-birds by 900 per cent.

In 1934, Prof. A. A. Allen, of the chair of ornithology at Cornell University, succeeded in rearing ptarmigan in captivity for the first time, hatching eggs obtained in the Hudson Bay region, under bantams. The Bureau of Biological Survey already possesses divisions studying water-fowl numbers, game conservation, predatory animal and rodent control, fur resources, with considerable numbers of reserves and stations, and there is an Alaska Game Commission. Bag limits are made to protect wild geese and other birds in many States, and methods of hunting and shooting are under legal control in many States.
E. $\mathrm{H}$. 